\title{
MANDATORY AUDIT FIRM ROTATION IN SPAIN: A POLICY THAT WAS NEVER APPLIED ${ }^{1}$
}

\section{IE Working Paper \\ WP06-21 \\ 8-05-2006}

Nieves Gómez-Aguilar

Nieves Carrera

\author{
Nieves Gómez-Aguilar \\ University of Cádiz \\ Duque de Nájera, 8 \\ Cádiz 11002 \\ Spain
}

nieves.gomez@uca.es

\author{
Emiliano Ruiz Barbadillo \\ University of Cádiz \\ Duque de Nájera, 8 \\ Cádiz 11002 \\ Spain
}

emiliano.ruiz@uca.es
Emiliano Ruiz Barbadillo
Christopher Humphrey

\author{
Nieves Carrera \\ Instituto de Empresa BS \\ María de Molina 12 \\ Madrid 28006 \\ Spain \\ nieves.carrera@ie.edu
}

\author{
Christopher Humphrey \\ University of Manchester \\ Crawford House \\ Manchester M13 9PL \\ UK \\ chris.humphrey@mbs.ac.uk
}

\begin{abstract}
In recent international debates on auditing regulation, Spain has assumed a real prominence as a claimed practical example of where a policy of mandatory audit firm rotation did not work and was duly abolished. This study provides an analysis of the implementation and removal of such policy in Spain. Using the evidence provided by congressional hearings, financial newspapers and other documents we demonstrate that at no stage was mandatory rotation of audit firms ever enforced on Spanish auditors. Further, the revision and subsequent removal of the Spanish law on mandatory rotation emerges as a rather politicised process, with no reference being made in the process of legislative reform to Spanish auditing experiences. A clear implication of the paper is that considerable caution needs to be taken in today's international auditing arena when analysing the standpoints and claims made by professional associations and the evidence they provide to support their arguments for and against regulatory reform.
\end{abstract}

\section{Keywords}

Mandatory audit firm rotation, Auditing regulation, Spain, Auditor independence

${ }^{1}$ Acknowledgements: The authors wish to thank the participants at the EARNET Conference 2003 (Manchester, October 2003) for their very useful comments on earlier versions of this paper. The suggestions and comments of José A. Angulo, Salvador Carmona, Brian Shapiro, Stephen Walker and Stephen A. Zeff, are also gratefully acknowledged. This research was partly funded by the CICYT's (Spain) project SEC 2001-0657. 



\section{INTRODUCTION}

The post-Enron era has witnessed a growing concern with issues of auditor independence and audit quality. The mandatory rotation of audit firms after a fixed period of tenure has again been suggested as an important way by which auditor independence could be enhanced (for a review, see Catanach \& Walker, 1999). The auditing profession and its regulators in different countries have been addressing and responding to claims that such a requirement would help to avoid the type of high profile corporate collapses and cases of audit failure of recent years (e.g., see ICAEW, 2002; Moizer, 2003; FEE, 2004).

Arguments for a mandatory rotation policy traditionally emphasise its potential to restrict managerial threats to change "non-compliant" auditors (Craswell, 1988; Petty \& Cuganesan, 1996; Lennox, 2000) and prevent the excessive familiarity that may erode audit quality (Deis \& Giroux, 1992; Raghunanthan, Lewis \& Evans, 1994; Zeff, 2003; Francis, 2004). Typical counter-arguments are that auditors have economic incentives to maintain their independence and that audit quality may be lower for new engagements due to the lack of auditor knowledge of the client (Johnson, Khurana \& Reynolds; Francis, 2004, p. 356).

With auditing firms and professional bodies, post-Enron, generally coming out against the introduction of mandatory audit firm rotation, much has been made of Spanish experiences with such a regulatory provision - with Spain being regularly cited in a wide range of academic papers, professional reports, and public speeches by national and international representatives of the accounting profession and auditing firms as a practical example of where mandatory audit firm rotation did not work. For instance, mandatory audit firm rotation in Spain has been held to have had a negative impact on the quality of auditors' work and on the structure of the audit market (e.g., Arruñada \& Paz-Ares, 1995; 1997; ICAEW, 2002; FEE, 2004). The rotation policy was incorporated in the 1988 Spanish Audit Law, requiring mandatory rotation of audit firms every nine years. Its subsequent removal in 1995 has been classified as a "rational" decision by regulators after verifying that the rotation rule "did not work" and "did not achieve its objectives of public policy" (e.g., US House of Representatives, 2002, p. 20).

This paper demonstrates that the experience in Spain has been rather different and somewhat more complex than the above statements imply. For instance, despite the claims from representatives of the accounting profession at international level, it is very clear from our historical analysis that at no stage was the mandatory rotation requirement enforced on Spanish auditors - i.e. Spanish audit firms did not in practice have to rotate in a statutory, mandatory fashion. The requirement was to apply for the first time to audit assignments starting in 1990, meaning that the first mandatory changes of auditors would have had to have taken place in 1999 - four years after the policy was formally abolished. Accordingly, instead of the "traditional" view portrayed by the international accounting profession of an experiment that did not work, mandatory audit firm rotation in Spain has to be regarded as a policy that was never given the chance to work. Further, the removal of the Spanish law on mandatory audit firm rotation also emerges as a fairly politicised process, with legislative changes appearing to have had only a very loose connection with professional audit practice a position well illustrated by the way mandatory audit firm rotation was reconsidered as a potential reform by Spanish politicians in 2002 when, internationally, Spain was being held out as a country to have abolished such a regulation on grounds of practical experience. 
Our research lends considerable empirical support to the claim that regulation in accounting and auditing is a "much more precarious process than suspected" (Fogarty, Zucca, Meonske \& Kirch, 1997, p. 181). The Spanish experience - and the way it has been used (or mis-used) in international debates on audit regulatory reform - also backs up the arguments of those who have questioned the transparency and accountability of professional and regulatory arenas and highlighted the growing influence of the multinational Big Four firms on policy processes (e.g., Cooper, Greenwood, Hinings \& Brown, 1998; Caramanis, 2002). Additionally, the paper highlights how academic research can be used in an opportunistic fashion by regulators and professional bodies to block or promote certain reforms. The Spanish case certainly emphasises that claims emanating from professional accounting circles need to be treated with a good degree of care and that careful, independent research has an important role to play in terms of opening up today's international audit policy arena to critical, but constructive analysis. Finally, although Spanish academic accounting research is assuming a growing international prominence, this paper, by seeking to get "inside" Spanish auditing and regulatory circles, illuminates the array of questions that still need answering regarding the development and internationalisation of auditing practice in Spain and the degree to which Spanish accounting firms, their auditing approaches and traditions as well as the general regulatory approach is changing.

The paper is organised into six subsequent main sections. Section 2 demonstrates the way in which the Spanish experience has been referenced in recent national and international debates on mandatory audit firm rotation. Section 3 provides a brief account of the history of auditing regulation in Spain and explores in detail the process by which mandatory audit firm rotation was originally established in Spain in 1988. Section 4 examines Spanish experiences with such a legislative requirement between 1988 and 1995. During this period (in 1993) there was a formal change in the interpretation of the law with respect to existing auditor tenure contracts and the subsequent repeal of the mandatory audit firm rotation requirement in 1995. Section 5 analyses the most recent (2002) attempt to establish mandatory audit firm rotation in Spain while Section 6, in closing the paper, reflects critically on what can be learned from the Spanish experience with mandatory audit firm rotation and how it develops the existing literature on international auditing regulation.

\section{THE GLOBAL SIGNIFICANCE OF SPANISH EXPERIENCES WITH MANDATORY AUDIT FIRM ROTATION}

The collapse of Enron and its auditors, Arthur Andersen, quickly led regulators worldwide to consider different mechanisms for enhancing auditor independence. The auditing profession has traditionally opposed the implementation of any mandatory regulatory requirement for audit firms to rotate after a given period of tenure (for example, ICAEW, 2002; FEE, 2004). What was interesting about the post-2001 regulatory debating arena was that arguments against mandatory audit firm rotation were not just made on academic or a priori grounds. They were frequently rooted in supposed practical experience, with Spain being highlighted as a clear case where such a rule did not work. The following paragraphs illustrate how the Spanish experience has been used by regulators, professional associations and international auditing firms worldwide to support their stance against mandatory audit firm rotation.

In the UK, the Co-ordinating Group on Audit and Accounting Issues (CGAAI), set up in February 2002 by the Secretary of State for Trade and Industry with the purpose of reviewing the UK's current regulatory practices for statutory audit and financial reported, highlighted the Spanish case as an illustration of the failure of mandatory audit firm rotation: 
"There is no strong evidence from Italy (which requires audit firm rotation every nine years for the 20 listed companies) or Spain (which abandoned a similar requirement for listed companies in 1995) of a positive impact on audit quality...” (p. 26).

$\cdots$

"In Spain, it was found that mandatory rotation reduced the incentive to improve audit quality and increased the number of first time audits with corresponding loss of accumulated audit knowledge" (p. 75).

(Final Report of the Co-ordinating Group on Audit and Accounting Issues to the Secretary of State for Trade and Industry and the Chancellor of the Exchequer 29

January 2003; CGAAI, 2003).

Discussions in the Treasury Committee concerning mandatory rotation of audit firms also highlighted the Spanish case:

“... certainly all our studies to date suggest that audit firm rotation does not work, certainly international experience suggests that it does not work, in countries like ... Spain ....”

(C. Reeves CBE, Director, The Review Board, in discussing the Memorandum submitted by The Review Board, the Auditing Practices Board and the Ethics

Standards Board of the Accountancy Foundation; Minutes of Evidence Treasury Committee, 25 June 2002. Question and answer 206. UK House of Commons, 2002).

In the US, the President of the American Institute of Certified Public Accountants (AICPA) in a speech to the House of Representatives referred to the Spanish case as a supportive example of the claim that audit firm rotation does not achieve its public policy goals:

"Finally, I must mention that at one time Greece, Spain and Italy all required mandatory auditor rotation. Greece and Spain dropped the requirement after determining that the concept did not achieve public policy goals."

(Mr B. Melancon, President and CEO, AICPA, Committee on Financial Services, 13 March 2002. US House of Representatives, 2002).

In New Zealand, the submission by the Institute of Chartered Accountants of New Zealand to the Securities Commission on Corporate Governance Principles, pointed out, in discussing mandatory audit firm rotation, that:

"Of the three countries that had tried audit firm rotation, Italy, Spain and Turkey, only Italy has persevered with it..."

(Submission to the Securities Commission Corporate Governance Principles; Institute of Chartered Accountants of New Zealand November 2003, p. $19^{1}$ ).

Professional associations have also used the example of Spanish practical experience with mandatory audit firm rotation to reject the implementation of such rule. In July 2002 the Institute of Chartered Accountants in England and Wales (ICAEW) published a report summarising the current requirements for rotation in different countries and the main results of academic research on mandatory audit firm rotation (ICAEW, 2002). Gendron \& Bédard 
(2001) argued that the use of academic research may help the auditing profession to maintain the legitimacy of its claims in the eyes of the government and public. In particular, rather than providing an objective description of the circumstances surrounding the implementation of a regulatory provision in a particular setting and a fair evaluation of all relevant academic research, professional bodies may deliberately avoid "threatening research" (Gendron \& Bédard, 2001) and give an account of events and results that fits their interests. Such behaviour does seem to have been evident in the way in which research on the Spanish experience with mandatory audit firm rotation has been reported by professional bodies. For instance, the report prepared by the ICAEW analysed in detail the results of two academic studies - one carried out in Italy (SDA Universitá Bocconi, 2002) and one in Spain (Arruñada \& Paz-Ares, 1995). Both studies were reported as providing empirical evidence against audit firm rotation, asserting that the policy imposes significant additional costs on the audit firms and auditees and has adverse effects on audit quality, especially in the early years of the audit contract.

Both studies are unpublished, and have, therefore, not been subjected to formal peer reviews. They have also proved very difficult for audit researchers to access (Moizer, 2003). For instance, at the time that the ICAEW report was published, the Universitá Bocconi paper had the status of being a "confidential" document and was officially not available for public inspection. A subsequent paper by the researchers from the Universitá Bocconi (presented at the European Audit Research Network (EARNET) Conference in 2003 - see Cameran, Livatino, Pecchiari, \& Vigano, 2003), does present a rather different conclusion to the one represented in the ICAEW report as to the impact of the rotation policy in Italy since its introduction in 1974. Cameran et al. (2003), using a questionnaire-based survey, found that corporate managers, internal auditors and external auditors "generally agreed that the current mandatory audit rotation rule constitutes a mechanism to guarantee auditor independence" (Cameran et al., 2003, p. 4). They also indicated that "the mandatory audit rotation rule does not seem to have had much impact on the level of competition in the mandatory audit segment" (p. 5). In fact, the level of concentration reported is similar to that reported for other countries (see for example Pong, 1999 for the UK position; Carrera, Gutiérrez \& Carmona, 2005 for Spain; and Wolk, Michelson \& Wootton, 2001 for the US). Regarding the impact of such a rule on audit costs, the paper shows that most interviewees believed that the costs of switching auditors either did not change or even dropped as a consequence of mandatory audit firm rotation. Finally, Cameran et al. found that 69 percent of managers approved of mandatory audit firm rotation while only 14 percent had a negative view of such a requirement. Moreover, many external auditor respondents (69 percent) indicated that a more frequent audit firm rotation requirement would have a positive impact on auditors' independence. To sum up, although the authors of the paper did believe that mandatory rotation "risks being simply a "persuasive" solution to the problem of independence" (Cameran et al., 2003, p. 8) the empirical evidence provided indicates that mandatory audit firm rotation is widely accepted by a range of different actors in the Italian audit market.

As mentioned above, the ICAEW report also relied on the Arruñada \& Paz-Ares (1995) study to conclude that mandatory rotation of audit firms has a negative impact on audit quality. The main purpose of the work by Arruñada \& Paz-Ares was to evaluate, in terms of efficiency, the system of obligatory audit firm rotation in Spain. They used mathematical modelling and computer simulations to demonstrate that mandatory audit firm rotation could harm auditor independence and may have a negative impact on the audit market. However, at no stage in their work did they draw directly on any empirical evidence from the Spanish audit market to 
make or support such a conclusion. Therefore, from their study no conclusions can be drawn about the actual, practical impact of mandatory audit firm rotation in Spain.

The Fédération des Experts Comptables Européens (FEE, 2004), in rejecting the policy of mandatory audit firm rotation, relied on the conclusions of such studies together with work done in different countries (for example, the conclusions presented by the CGAA in the UK). Spain was once again highlighted in FEE's report as an example of the negative impact of such a regulation:

"In Spain, the Statutory Audit Law of 1988 introduced mandatory rotation after a maximum period of nine years with a prohibition to take up the same audit engagement before at least a three-year period has elapsed. The Limited Liability Partnership Act of 1995 removed such prohibition and in fact abolished the mandatory rotation requirement. Subsequently, the Spanish Government funded the Arruñada and Paz-Ares [...] report which supported this decision” (p. 6).

"There is no strong evidence from Italy (which requires audit firm rotation every nine years for the 20 [audit firms of] listed companies) or Spain (which abandoned a similar requirement for listed companies in 1995) of a positive impact on audit quality" (p. 14).

(FEE Study on Mandatory Rotation of Audit Firms, 2004²).

Finally, the vast majority of the top 30 accounting firms in countries such as the UK rejected audit firm rotation as a legitimate post-Enron regulatory reform (Accountancy Age, 9 January 2003, p. 14). Again, Spain was cited to support the case against mandatory rotation:

"Only in Italy is audit rotation currently mandatory.... Spain had a similar provision but has recently withdrawn it. The conclusion is a compelling one: mandatory audit firm rotation is a bad idea."

(PricewaterhouseCoopers, 2002).

The Spanish legal position with respect to mandatory audit firm rotation has been very briefly referred to in a few academic papers (e.g., Catanach \& Parker, 1999; Moizer, 2003; Ng, 2003; Zeff, 2003). Both Zeff (2003, p. 2, footnote 3) and Moizer (2003, p. 16) noted that Spanish auditors did not have to rotate in a mandatory fashion due to the fact that the rule was removed before the statutory maximum length of a post-1988 Spanish audit engagement had been exceeded. Ng's (2003) historical review of the concept of mandatory audit firm rotation referred to the Spanish experience as one where the policy was abandoned after a trial period, but also noted that the legislation was repealed before it would have had an impact $^{3}(\mathrm{Ng}$, 2003 , p. 2). Despite such references, there has been no detailed analysis of what really happened in Spain and why the audit firm rotation requirement was removed before any Spanish audit firm was required to rotate in a mandatory fashion.

Our starting point with this paper, therefore, is to clarify the nature of Spanish experiences with such a regulatory policy. Contemporary accounting historians (e.g. see Mills, 1990; Parker, 1999; Previts, Parker \& Coffman, 1990; Lee, 1995; Carnegie \& Napier, 1996; Chandler \& Edwards, 1996; Funnell, 1996; 1998) have demonstrated the value of providing alternative histories which challenge the accepted or assumed historical position and the case of mandatory audit firm rotation in Spain is no exception in this regard. At a very basic level, 
it demonstrates very clearly that Spain cannot be held up as a proven practical example of the failings of mandatory audit firm rotation. At another level, tracing through the introduction, revision, removal and attempted re-introduction of such a regulatory policy in Spain highlights the political nature of audit regulatory processes in Spain and also casts additional light on the professional status of auditors in Spain. Finally, the case allows for an assessment of the broader significance of Spanish experiences being so fundamentally misrepresented on the international regulatory stage. In particular, we consider what such misrepresentation says about the role and significance of independent academic research - and how best to treat (and respond to) the "expert" views of professional accounting associations and the large, international audit firms on the nature of their operating environment and the efficacy of existing and proposed regulatory provisions.

\section{AUDIT REgULATION IN SPAIN AND THE INTRODUCTION OF MANDATORY AUDIT FIRM ROTATION}

The commencement of Spain's membership of the European Union (EU, then the European Economic Community, EEC) in January 1986 was influential in shaping several of its financial reporting reforms (Bougen \& Vázquez, 1997; Ruiz-Barbadillo, Humphrey \& GarcíaBenau, 2000). For instance, the Spanish Audit Law, enacted in 1988, was a direct response to EEC/EU company law directives and established, among other things, mandatory audits for medium- and large-sized companies. Before 1988, only a few companies, such as state-owned companies and firms in regulated industries, had had compulsory audits.

The debate on the 1988 Audit Law in the Spanish parliament focused mainly on the recognition and regulation of audit professionals (Bougen, 1997; Ruiz-Barbadillo et al., 2000). The ruling socialist party (PSOE, Partido Socialista Obrero Español) proposed an interventionist model, with a new statutory regulatory body, ICAC (Instituto de Contabilidad y Auditoría de Cuentas, Accounting and Auditing Institute) with considerable capacity to monitor the work of auditors (García-Benau \& Humphrey, 1992; Ruiz-Barbadillo et al., 2000). For PSOE, auditing was regarded more as an activity than a profession and as such was not really seen to be something capable of justifying professional claims for selfregulation (Bougen, 1997; Bougen \& Vázquez, 1997; Ruiz-Barbadillo et al., 2000). The opposition party (PP, Partido Popular), however, demanded a self-regulated audit profession governed by the three existing professional associations of auditors - Instituto de Censores Jurados de Cuentas de España (ICJCE); Registro de Economistas Auditores (REA) and Registro General de Auditores (REGA). The parliamentary majority enjoyed by PSOE ensured that the 1988 Audit Law encompassed its proposals and ICAC, an agency responsible to the Spanish Ministry of Economy and Finance, was duly established. ICAC's powers included, among other things, responsibility for a disciplinary regime for auditors, the capacity to investigate audit work performed by registered auditors, audit quality control systems and the adaptation of audit legislation to EU directives (García-Benau \& Humphrey, 1992; Ruiz-Barbadillo et al., 2000, pp. 123-124). The 1988 Audit Law did not take into account the claims of professional associations of auditors and did not assign rights or historical privileges to any of the three existing associations. Under the law, all professionals wishing to become an auditor, whether or not they were members of any of the existing bodies, had (a) to have a university degree, (b) to enrol in theoretical training programs and (c) to be able to demonstrate some practical experience. As these requirements were not very demanding, there was an extraordinary number of applications to become a registered auditor (over 50,000), with the final number of registered auditors being around 13,000, double the membership of existing professional bodies (Ruiz-Barbadillo et al., 2000, p. 123). 
The 1988 Audit Law also established the requirement for (mandatory) audit firm rotation. Prior to this law, there had been attempts in Spain to introduce an obligatory change of audit firms after a fixed number of years- with the draft of the Limited Companies Act in 1975 (Anteproyecto de Ley de Sociedades Anónimas) and the draft of the Accounting and Auditing Reforms in 1983 (Anteproyecto de Reforma Contable y Auditoría) both including a requirement for mandatory rotation of audit firms. However, neither of these projects became law with typical reasoning for such a lack of development being that the EEC, at that time, was publishing new company law directives - directives "... to which Spain would have to adapt sooner or later, and therefore it was better to wait and see" (Casanovas Parella, 1992, p. 172; quoted in Bougen \& Vázquez, 1997, p. 3).

The draft 1988 Audit Law (Proyecto de Ley de Auditoría de Cuentas, 121/000054, 20/October/1987) proposed a system of mandatory audit firm rotation whereby the audit firm's appointment would last for no less than three years and no longer than nine years (art. 8.4). Under such a proposal, once the audit firm's appointment had terminated, it would have to be replaced and could not seek reappointment until a further three years had passed. Once the appointment was signed it was irrevocable unless a fair cause (causa justa) arose although the audit legislation did not define what fair cause meant. During the subsequent parliamentary debate, opposition parties showed their disagreement with such a proposal. Some parties supported a more severe rotation measure (e.g., Partido Popular), while others demanded the removal of any requirement for compulsory change of auditors (e.g., Convergència $i$ Unió, CiU). In particular, the Partido Popular (PP) argued for mandatory audit firm rotation every three years. Interestingly, this proposal was endorsed in the parliamentary debate by Mr Pont Mestres, who was at that time the president of the leading association of auditors, the ICJCE. The argument to support such a proposal was that:

[The rotation of audit firms every three years will] "ensure auditors' independence ... and avoid the concentration of financial information in the hands of few large auditing firms..."

(Enmienda núm. 45, Boletín Oficial de las Cortes Generales, III Legislatura, Serie A. Núm. 53-55, 3 December 1987).

Other parties, such as Convergència i Unió (CiU) and Partido Liberal, attempted to avoid the implementation of any kind of restriction on the length of the audit firm's engagement. CiU, the dominant party in Catalan regional politics and the third largest parliamentary group in the Congress of Deputies at that time (Morlino, 1995, p. 344), demanded that the length of the contract should be for a minimum of three years and a maximum of six years, with the reappointment of the auditor being possible after the contract period had been completed. CiU relied on European Directives and the exceptional nature of the Italian case (the only European country where rotation of audit firms was mandatory) to justify the proposal, stating that:

"Our amendment is in accordance with the draft of the Fifth Directive of the EEC.... After six years of an auditor-auditee relationship, a time for reflection may be recommendable. However, it should not imply a mandatory break in the professional relationship." 
(Enmienda núm. 133, Boletín Oficial de las Cortes Generales, III Legislatura, Serie A. Num. 53-55, 3 December 1987).

The parliamentary majority enjoyed by PSOE again ensured that all of the proposals made by the opposition parties were rejected and not incorporated in the 1988 Audit Law. The result was a mandatory audit firm rotation requirement that could technically apply any time between three and nine years after the start of the audit firm's tenure (depending on the precise form of the auditor's contract). That is, once the initial contract (which could have been signed for a minimum period of three years and a maximum of nine years) expired, the company was required to switch its auditor.

\section{A SHORT-LIVED REgULATION: THE REVISION AND SUBSEQUENT REMOVAL OF MANDATORY AUDIT FIRM ROTATION}

In the early 1990s the public reactions of Spanish auditing firms regarding the rule of mandatory rotation of audit firms was not homogeneous. While the then chairman of Arthur Andersen in Spain noted, rather disparagingly, that the rule was "like a Mediterranean disease" (making reference to the cases of both Spain and Italy - see International Accounting Bulletin, 5 April 1993, p. 2), some small audit firms were reported as seeing positive nuances in such a regulatory requirement (see International Accounting Bulletin, 5 April 1993, p. 2). Generally, the claims of professional associations to remove the policy of mandatory audit firm rotation did not rely on detailed arguments or analysis of the Spanish audit context - the basic claim was that "the rule must be wrong" because it had only been implemented in just one other European country, Italy (see Durández, 1991; López-Combarros, 1996).

Two empirical studies carried out at that time (García-Benau et al., 1993; Prado-Lorenzo et al., 1995) showed that mandatory audit firm rotation was not well regarded by the Spanish audit profession - although it was something that had not been objected to at the time of the debate of the Audit Law in 1988 and had, in fact, been supported by the then president of ICJCE. García-Benau et al. (1993) compared the views on the nature and standard of auditing practice in Britain and Spain. Perceptions of auditors, financial directors and users of corporate financial statements were obtained from two questionnaire surveys covering a range of issues including their perception of mandatory audit firm rotation. The answers showed that British auditors were strongly against the proposal that an audit firm should have a maximum period of office ( 80 percent of auditors disagreeing with such a proposal). In Spain, a significantly lower but still clear majority of auditors (59 percent) were against the mandatory rotation of audit firms (García-Benau, Humphrey, Moizer \& Turley, 1993, p. 300). Prado-Lorenzo, Gonzalo-Bravo \& Martín-Jiménez (1995) analysed the perceptions of Spanish auditors about mandatory rotation by using data collected from questionnaires sent to individual auditors and audit firms (234 responses) between November 1992 and April 1993. Both individual auditors and members of audit firms rejected any restriction on auditors' reappointment (Prado-Lorenzo et al., 1995, p. 653).

The pressure for reform was driven in the early 1990s by the fact that a substantial number of audit contracts were due to end in 1993 (the first audits under the 1988 Audit Law not being undertaken until 1990). Traditionally, auditing had not been extensively practised in Spain (García-Benau \& Humphrey, 1992), resulting in companies subject to statutory audits for the first time acting "prudently" and only engaging auditors for the minimum three-year period (Petit, 1995). There were suggestions, though, that such initial prudence was seen to have been excessive, with the various start-up costs associated with a new auditor (following the 
mandatory change) not necessarily being seen as desirable (for a discussion, see Petit, 1995). There were also concerns over the practical feasibility of switching many audit firms:

"The first three-year term mandated by the Spanish audit law of 1988 has expired, and leading firms are awaiting a bureaucratic nightmare as some of the rules are found to be unclear and unworkable".

(International Accounting Bulletin, 5 April 1993, p. 2).

The response of the profession was to demand extensions to the three-year appointment period - up to the maximum length of nine years - and thereby delay the implementation of mandatory audit firm rotation (see Expansión, 21 October 1993; Expansión, 25 October 1993; Expansión, 28 October 1993). The particularities of the Spanish audit market could potentially be held to have contributed to the aura of uncertainty as to what would happen if mandatory rotation of audit firms was applied. For example, according to available statistics, in 1995 42\% of audit firms in Spain (companies and self-employed professionals) had only one client, while 76.4\% had less than five clients (Expansión, 22 February 1995). In such circumstances, mandatory audit firm rotation would trigger a significant diminishing in the audit firm's portfolio, particularly if the firm failed to secure new audit clients. In pursuing extensions in audit contracts, the professional auditing bodies in Spain focused on what they argued was an imprecise and ambiguously worded article 40.1 of the Audit Law (Royal Decree 1636/1990 of 20 December). They argued that the Law had established a maximum number of years for the audit contract and, as such, any extension would not infringe the law so long as it did not exceed the maximum period of nine years (Expansión, 25 January 1992).

Auditors in practice raised several questions to the regulatory body ICAC (see Consulta No 8 BOICAC 4, January 1991; Consulta No 6 BOICAC 12, March 1993) regarding the legality of the extensions and the interpretation of the articles about mandatory audit firm rotation in the: Audit Law; Regulations of the Audit Law (Reglamento de la Ley de Auditoría, 1990); and the 1989 Companies Act (Texto Refundido de la Ley de Sociedades Anónimas). ICAC's interpretation subsequently permitted such extensions, arguing that according to the interpretation of the rule it was possible for the reappointment of the same auditor to be made after the termination of the (initial) contract as far as such an extension will not exceed the maximum of nine years (BOICAC No. 4 Consulta 8 January 1991; BOICAC No 12 Consulta 6 March 1993).

With the right to extend audit appointments secured, the issue of mandatory audit firm rotation then seemed to go relatively quiet in Spanish auditing circles. Once it was permitted to extend audit contracts until 1999, any prospective mandatory audit firm rotation presumably must have seemed a relatively long way away. Further, the audit market was showing an extraordinary rate of growth, with the number of mandatory audits in 1994 being more than ten-fold higher than in 1990 (22,184 compared to 2,210 - see BOICAC No 5 May 1991, BOICAC No 21 April 1995), so Spanish audit firms generally did not appear to be under any imminent threat of a declining audit client base. The Spanish audit profession also chose to focus its criticisms on apparently more contentious aspects of the 1988 Audit Law, especially regarding the interventionist nature of ICAC and its policy of financially sanctioning audit firms found to have breached minimum audit quality standards. For example, between 1992 and 1996 the number of sanctions imposed by the ICAC was 38 (being the total number of audits 162,394) of which 47 percent (18) were economic sanctions, 32 percent (12) implied a "public warning" and the remaining 21 percent (8) implied the 
removal of the auditor/audit firm from the list of registered auditors for a given period of time (Navarro-Gomollón \& Bernad-Morcate, 2004, p. 13; for more discussion, see GonzaloAngulo \& Gallizo, 1992; García-Benau \& Humphrey, 1992; Expansión, 16 October, 1995; García-Benau, Ruiz-Barbadillo, Humphrey \& Al Husaini, 1999). Although some Spanish commentators did emphasise the need to remove mandatory audit firm rotation (e.g., see Iglesias, 1994), there was no real public debate pressurising regulators to make any such revisions to the Law.

Internationally, two studies published in 1992 (see the Cadbury Committee Report, 1992; AICPA, 1992) highlighted the excessive costs of mandatory audit firm rotation and did not recommend it as a regulatory reform to be pursued in the UK and USA respectively. The suggestions and conclusions of these reports were introduced in Spain, albeit with a certain delay, by academics (see Arruñada \& Paz-Ares, 1994; 1995; Gonzalo-Angulo, 1995; PradoLorenzo et al., 1995). Arruñada \& Paz-Ares (1994), drawing on international research, summarised the arguments against mandatory rotation. In subsequent studies (Arruñada \& Paz-Ares, 1995; 1997), they sought to demonstrate theoretically that the start-up costs or "first time through" costs associated with a new auditor appointment were unacceptably high and outweighed the potential benefits of rotation. They also argued that the mandatory change of audit firms was not acceptable due to the negative effects on the audit market, with the regulation generating a reduction in incentives to compete and, overall, leading to a general reduction in audit quality. Similar arguments were provided by Díaz (1995), who pointed out that Spanish companies could hardly be expected to assume the increased audit costs caused by mandatory rotation when they were already under pressure to improve their international competitiveness given the prospect of a European market for audit services.

In January 1994, a draft of the Limited Liability Companies Act (Ley de Sociedades de Responsabilidad Limitada) was tabled in the Congress of Deputies ${ }^{4}$. During the debate in the Congress, there were no indications that this law was going to serve as a mechanism for removing mandatory audit firm rotation. The debate on the Act started on 25 January 1994 and was not completed until $9^{\text {th }}$ March 1995, when the Act was finally approved by the Congress of the Deputies. Amendments to the draft were tabled between $8^{\text {th }}$ February and $7^{\text {th }}$ May 1994 but neither these nor the debate as a whole made any reference to mandatory audit firm rotation. It was only in the subsequent debate on the Act in the Senate that the issue emerged - via two amendments put forward by CiU. Amendments 274 and 275 demanded a change to the articles directly related to mandatory audit firm rotation in the Companies Act and in the Audit Law. Specifically, CiU's proposal was that:

“...auditors will be appointed for a given initial period of time which cannot be lower than three years or higher than nine years since the date of the first accounting year audited by the audit firm. They may also be reappointed".

(Enmienda No 275 Del Grupo Parlamentario Catalán en el Senado. Convergència i Unió. Boletín Oficial de las Cortes Generales V Legislatura. Serie 11. Proyectos de Ley 23 diciembre de 1994. Num. 53 (d). Num. Exp. 1211000034, p. 110).

To justify such a proposal CiU argued that it was in concordance with the requirements of the draft of the $5^{\text {th }}$ Directive of the (then) EC which did allow for the indefinite reappointment of auditors (Enmienda No 275 del Grupo Parlamentario Catalán en el Senado. Convergència i Unió. Boletín Oficial de las Cortes Generales V Legislatura. Serie 11. Proyectos de Ley 23 diciembre de 1994. Num. 53 (d). Num. Exp. 1211000034, p. 110). 
Amendment No 275 tabled by CiU was incorporated in the government's draft bill with one modification. Instead of allowing the reappointment period to be extended from anywhere between three and nine years before being reassessed by the members of the company, the draft approved by the Senate and sent (back) to the Congress of Deputies required auditors to be reappointed annually once the first appointment period had finished (Disposición Adicional Sexta Ley de Sociedades de Responsabilidad Limitada, 1995). Although there is no evidence in the discussions in the Senate and subsequent discussions in the Congress of Deputies as to the reasons used to justify such a modification, the Spanish financial press (see Expansión, 26 January 1995, p. 29), suggested that PSOE believed that the removal of mandatory audit firm rotation was good and beneficial for auditors and companies but that its removal did not provide sufficient guarantees to other third parties affected by auditors' work. Accordingly, PSOE sought to avoid organisations/auditors getting tied into long-term engagements (which could be very likely as a result of the removal of rotation) by imposing an annual reappointment process - although it appears that PSOE did not explicitly consider the negative impact that an annual engagement system could have on auditor independence, with auditors becoming potentially more vulnerable to the demands of client management. In the final debate on the draft law in the Congress of Deputies, a Partido Popular representative, Mr Fernández de Trocóniz Marcos, was the only one to criticise the annual reappointment of auditors - arguing that sooner or later its reform will be demanded (because of social pressure or EU regulations) in order to allow companies to reappoint their auditors for, at least, a period of time similar to that of their first appointment (Diario de Sesiones, V Legislatura, Núm. 131 Sesión plenaria Núm. 129, 9 Marzo de 1995, p. 6947). The Limited Liability Companies Act, with the additional disposition number six specifying the removal of mandatory audit firm rotation, was duly published in May 1995. Article 8.4 of the Spanish Audit Law and article 204.1 of the Companies Act were modified accordingly, such that:

[auditors] "will be appointed by a given initial period, which cannot be lower than three years nor higher than nine years...They may also be reappointed (but only on an annual basis) once the initial period of appointment finishes".

(Disposición adicional sexta. Modificación de la Ley de Auditoría de Cuentas. Ley 2/1995 de 23 de Marzo de Sociedades de Responsabilidad Limitada, p. 255).

It is quite clear from our review of parliamentary documents that no Spanish political party in the Congress of Deputies expressed disagreement with the removal of mandatory audit firm rotation. The modification of the Audit Law was also approved unanimously by the Committee of Justice (Comisión de Justicia) in the Senate (Diario de Sesiones del Senado, V Legislatura, Comisión No. 166 Comisión de Justicia, 15 de Febrero de 1995, p. 24). The change in Spanish law on audit firm rotation also appears to have been approved without any explicit recognition being given to the views of key investors or other user groups, or even those of the main regulatory body, ICAC. Indeed, the then president of ICAC, Mr Ricardo Bolufer, publicly expressed his disagreement with such a decision in different media arguing that once the rotation rule is removed it would be necessary at least "to analyse the convenience of rotation of audit partners and audit teams" following the Cadbury Committee's recommendations in the UK (Expansión, 4 February 1995, p. 34).

What is probably most surprising with respect to the removal of mandatory audit firm rotation is that it came at a time when Spain had just experienced a number of major financial scandals. These scandals had raised serious questions over the effectiveness and independence 
of auditors, with regulators imposing some quite substantial fines on the major, international audit firms (see García-Benau et al., 1999; Expansión, 3 November 1994, p. 3). For example, as a result of one of the most notorious financial scandals in Spain involving the financial institution Banco Español de Crédito (Banesto), Price Waterhouse was fined Pta127 million (approx. 763,285 Euros -3\% of its annual fee income) by the ICAC for its inadequate audit of Banesto's 1992 accounts and its report on the share issue of the company in 1993 (GarcíaBenau et al., 1999, p. 706). Such incidents had brought discussions on the auditing expectations gap to Spain, a concept that, contrary to the situation in other countries such as the UK, had not had any prior operational significance in Spain (see García-Benau \& Humphrey, 1992, p. 312; García-Benau et al., 1993; El País, 27 November 1994, p. 29). It is rather ironic that one of the rules so often labelled as a way of reinforcing auditor independence vanished when the Spanish auditing profession was evidently struggling to satisfy social expectations.

With the mandatory audit firm rotation provision being removed before it was allowed an opportunity to work in Spain, there are grounds for suggesting that its removal was more due to political convenience rather than regulatory ineffectiveness - a commodity exchanged for political support in the (political) market for legislative proposals (see Gibbons, 1999, p. 135). The ruling socialist party (PSOE) had enjoyed a parliamentary majority when the Spanish Audit Law was enacted (and the mandatory audit firm rotation policy introduced) in 1988. However, following the 1993 general election, PSOE remained the governing party in Spain but no longer had a parliamentary majority - being reliant on the support of minority political parties. Post-1993, PSOE struck agreements annually with CiU in return for parliamentary support, giving $\mathrm{CiU}$ some degree of influence over the main PSOE government agenda. These agreements included considerable concessions for Catalonia but also commitments to greater overall budgetary stringency and labour market flexibility, in keeping with CiU's economic liberalist stance (see Gibbons, 1999, p. 105; pp. 120-121). In terms of mandatory audit firm rotation, PSOE appears to have made a political agreement with $\mathrm{CiU}$ :

"The Socialist Group will support CiU's proposal to remove the requirement of mandatory rotation of audit firms every nine years from the draft Limited Liability Companies Bill [...]. By doing so, PSOE attempts to seek the support of CiU to approve a new regulation on "Employee-owned Companies".

(Expansión, 26 January 1995, p. 29)

As mentioned in the previous section, CiU had expressed its disagreement with any kind of mandatory audit firm rotation policy when the draft of the 1988 Spanish Audit Law was first debated in the Parliament. However, it has been suggested that its 1994-95 initiative on this issue in the Senate was strongly influenced by pressures and demands made by the Spanish auditing profession. This was the reported view of a representative of $\mathrm{CiU}$ in an interview published in a professional journal (see Newsletters, 10 February 1995). From such a standpoint, the audit profession effectively took advantage of Spanish legislative procedures and the on going review of other (non-audit related) company law provisions to negotiate and put pressure on a political group $(\mathrm{CiU})$ that it knew already had a positive attitude towards the removal of mandatory audit firm rotation (Amesti, 1995; Petit, 1995). Gonzalo-Angulo (1995, p. 617), a senior Spanish accounting academic, has also acknowledged such pressures, albeit without naming any political group: 
"...the discomfort of the auditing profession with the sword of Damocles of rotation policy has led, six years after the approval of the Audit Law, to new legislation to remove the mandatory rotation of auditors. The profession, by spreading their powerful tentacles, has received the support of certain parliamentary groups for the removal of a cumbersome, threatening and supposedly dangerous measure..."

(Gonzalo-Angulo, 1995, p. 617)

\section{THE REMERGENCE OF MANDATORY AUDIT FIRM ROTATION AS A REGULATORY SOLUTION}

The Enron/Andersen affair, post-2001, has raised major concerns internationally about auditor independence, audit quality and the need for regulatory action. Although the implementation of mandatory rotation of audit firms was considered by regulators in different countries such as the US and the UK as a potential way to enhance the perception of independence of auditors, its implementation was generally not recommended on the grounds that its costs were said to exceed its benefits (e.g., see the Government Accountability Office's Report on Mandatory Rotation (GAO, 2003) in the US, the Final Report of the Co-ordinating Group on Audit and Accounting Issues (CGAAI, 2003) and the Report of the ICAEW on mandatory rotation (ICAEW, 2002) in the UK). As illustrated earlier in this paper, Spanish experience was used to support such claims against rotation. However, what has never been reported in the international literature is that, at this very moment of international auditing crisis and debate, Spanish regulators were in fact considering whether there was a case for reestablishing mandatory rotation of audit firms in Spain.

This process started when, in March 2002, the Spanish government of the Partido Popular 5 tabled, in the Congress of Deputies, a parliamentary bill entitled "Ley de Medidas para la Reforma del Sistema Financiero" (Measures for Reforming the Financial System Act) popularly known as "Ley Financiera" (Financial Law). The Preamble of the Financial Law established its three main objectives: to guarantee that the legal system does not impose unnecessary constraints on Spanish financial institutions which would put them at a certain disadvantage in comparison to their European counterparts; to improve the protection of users of financial services given the higher level of competitiveness in the market and the use of new technologies; and to help to channel savings into the real economy by improving the mechanisms available for small and medium size enterprises (SMEs) to obtain financial resources.

Although the Financial Law did not have among its objectives the desire to modify the regulatory framework of auditing and nor did the draft legislation tabled in the Congress include any modification of the Spanish regulatory framework dealing with the audit function, several parliamentary groups, including the leading party Partido Popular, tabled amendments relating to auditing issues. In particular, there were several proposals for the introduction of mandatory rotation of auditors. Table I summarises the different proposals presented by the political groups in the Spanish parliament.

The government (Partido Popular, PP) proposed to re-establish mandatory audit firm rotation every twelve years for listed companies arguing that this requirement would help "to ensure independence in the auditor-client relationship" (Congreso de los Diputados, Enmienda 168, 
17 May 2002). The debate on legislative amendments in the Congress showed that the government took for granted that mandatory audit firm rotation had a positive impact on auditor independence (Congreso de los Diputados, Diario de Sesiones, 504, 29 May 2002, p. 16170). The representative of Partido Popular in the parliamentary discussions of the Financial Act, Mr Cámara Rodríguez-Valenzuela, pointed out that:

“...audit firm rotation is not a new subject and it has been discussed for many years internationally within professional auditing circles in countries such as the US ...”

(Congreso de los Diputados, Diario de Sesiones, 504, 29 May 2002 p. 16168).

This awareness of debate on the subject seemingly, however, did not extend to any acknowledgement of the criticisms that had been internationally of mandatory audit firm rotation, nor did it generate any reference to the fact that such a mandatory requirement had only recently been removed in Spain. Such a proposal was immediately rejected by professional auditing bodies:

“...the proposals made...are more interventionist than the current rules"

(Mr J.M. Gassó, President of the ICJCE; Cinco Días, 9 May 2002).

“Audit rotation issue should wait until Brussels recommendations".

(Mr L. Lara, President of the REGA; Cinco Días, 9 May 2002).

Even the president of ICAC at that time (López Combarros, a former partner of Arthur Andersen) argued that the temporal limitation of the auditor-client relationship was an interesting proposal but one that necessitated a wide-ranging debate (El País, 19 May 2002). The large audit firms were clearly unhappy with PP's proposal, potentially being forced, at some stage in the future, to pass on a significant part of their clientele to other audit firms (for a discussion, see Cinco Días, 9 May 2002). As the president of KPMG commented:

"...with the exception of Italy, there is no compulsory audit firm rotation in any other country, and even there, after ten years using this system, different studies conclude that either groups of professionals leave the audit firm... following their clients or audit firms agree to swap their clients. This is a clear signal that rotation is not efficient and it only causes market distortions. On the contrary, rotation of the audit partner and the gradual change of audit teams ...is something that many audit firms have been done for years and it works".

(Mr J.L. Pérez Rodríguez, President of KPMG, Nueva Economía, El Mundo, 14 July 2002).

In seeking to understand the government's attitude, it is important to recognise that the Ley Financiera (Financial Law) was attempting to increase and reinforce the confidence of investors in Spain, not just due to the international outcry over Enron but also several, unrelated, Spanish financial scandals, the most infamous of which was Gescartera (for a review, see Vico-Martínez, 2002). In comparison to the immediate aftermath of the Banesto case and a string of other corporate failures in the early 1990s (see García-Benau et al., 1999), the presence of the Spanish audit firms in the mass media in relation to matters of auditing 
and audit expectations had, by the end of the 1990s, become relatively limited (Expansión, 28 July 2001). The Gescartera case, however, had a significant impact on public opinion concerning standards of governance and regulation due to the sheer magnitude of the fraud and its political implications. Gescartera was a brokerage firm that invested in the stock market and became involved in the Spain's worst stock-market fraud leaving €87 million unaccounted for. It provoked high profile resignations including those of the chairwoman of the national stock market watchdog (Comisión Nacional del Mercado de Valores) and a junior finance minister whose sister helped run the brokerage house. The fact that Deloitte \& Touche gave Gescartera clean audit reports in its most recent financial years put auditing and the audit profession back in the public spotlight.

In response to Partido Popular's proposal to reintroduce mandatory audit firm rotation, the opposition parties proposed rotation of audit teams and audit partners. In particular, in the debates in the Congress of Deputies, the senior representative of the socialist party (PSOE), Mrs Costa Campí, made explicit reference to Gescartera (and Enron) in justifying the need for tighter independence measures, including proposed mandatory audit partner rotation every five years for listed companies, companies in which the public sector participates in any proportion and for companies subject to mandatory audit (Congreso de los Diputados, Enmienda 114, 17 May 2002). PSOE's recommendations closely followed the ECOFIN recommendations ${ }^{6}$ (proposed after the ECOFIN meeting in Oviedo, Spain, April 2002) and the on-going debate in the USA after the Enron scandal:

"We share with other political parties the concerns about the auditor's economic bond with the client, as evidenced in the Gescartera and Enron's cases (...). As far as the rotation of audit teams is concerned, our amendment follows the recommendations of the ECOFIN (...) by establishing mandatory rotation of audit teams every five years. We believe, however, that some improvements in this area are required. As a result of the events related to Enron, the American House of Representatives is debating a new Act to reform the regulatory framework for auditing (...). I invite members of this Parliament to visit the website of the American House of Representatives and to read the debate of the $18^{\text {th }}$ of March when the rotation rule every four years was discussed. It is important to take this into account because, although the ECOFIN recommended rotation (...) every seven years, this recommendation may change in the future following the decisions in the U.S. (...)".

(Cortes Generales, Diario de Sesiones del Congreso de los Diputados. Comisiones. Año 2002 VII Legislatura Núm. 504. Economía y Hacienda. Sesión núm. 49, Miércoles 29 de mayo 2002, p. 16153).

CiU proposed that auditors should be engaged for an initial three-year period and, then, be available for reappointment for periods of similar duration. For listed and supervised companies, $\mathrm{CiU}$ wanted the rotation of audit partners every seven years. CiU argued that this measure would help to reduce the links between auditors and clients, without damaging the quality of audit services and the level of competition in the audit market. Again, this proposal was justified on the basis that it followed the ECOFIN recommendations (Oviedo, April 2002) and the most recent experiences in other European countries (Congreso de los Diputados, Enmienda 241, 17 May 2002).

The eventual outcome of the parliamentary discussions saw an agreement reached between the government (PP) and $\mathrm{CiU}$ over auditor rotation. PP duly tabled an amendment which in 
the main followed CiU's proposal, with the final draft of the law containing no provisions regarding mandatory audit firm rotation. Instead, it established mandatory rotation of the audit partner and the audit team every seven years, in line with the EU's recommendations ${ }^{7}$, for listed companies, supervised companies (such as insurance companies) and for those companies with a turnover higher than $€ 30$ million. After three subsequent years, the company could engage again with the same audit partner (Senado, Serie II, num. 86-a, Texto remitido por el Congreso de los Diputados, art. 50.4, 24 June 2002).

During the parliamentary debate, CiU did recognise its contacts and negotiations with members of the audit profession (Congreso de los Diputados, Diario de Sesiones, 504, p. 16157, 29 May 2002):

"The Grupo Popular 8 had tabled an amendment in which they fixed the duration of the audit contract (...). Due to the crucial importance of this amendment for the auditing sector, and after the contacts we have had with the Grupo Popular, with those affected by the amendment [the auditors], and also following the legislation and recommendations of the EU, Convergència I Unió has tabled an amendment which goes into, let's say, a similar direction to that tabled by the Grupo Popular".

(Cortes Generales, Diario de Sesiones del Congreso de los Diputados. Comisiones. Año 2002 VII Legislatura Núm. 504. Economía y Hacienda. Sesión núm. 49, Miércoles 29 de mayo 2002, p. 16157).

Although expressing their satisfaction with the proposed legislation and the agreement forged between PP and CiU about the issue of mandatory rotation (5 Días, 30 May 2002; El Mundo, 14 July 2002), once the draft Financial Law was submitted to the Senate, the professional accounting associations (e.g., REA and REGA) showed their disagreement with certain aspects of the draft Law and consequently submitted proposals asking for further changes (e.g., REA, 2002; REGA, 2002). In particular, they requested the possibility of renewing the auditor's contract for three years instead of the annual reappointment established in the draft bill. They also wanted to increase the turnover limit over which companies are required to rotate their audit teams and partners (from $€ 30$ million to $€ 100$ million) (REA, 2002). Different political groups proposed amendments to the draft Law largely following the recommendations described above. CiU again played a very active role in the debate, seeking an increase in the turnover limit (from $€ 30$ million to $€ 60$ million) and an increase in the length of the reappointment of the audit firm from one year to three years (Senado, Enmiendas 115, 179, 207, 17 September 2002). None of the amendments tabled in the Senate, however, were accepted and the draft Law was finally passed in the Congress of Deputies on $31^{\text {st }}$ October, 2002 (Ley 44/2002, de 22 de Noviembre, de Medidas de Reforma de Sistema Financiero) with the support of PP, CiU and Coalición Canaria (nationalist representatives from the Canary Islands) ${ }^{9}$. With the approval of the Financial Law, Article 8.4 of the 1988 Audit Law was modified to include the provision for mandatory rotation of audit partners and audit teams. Some professional bodies, specifically those representing the interest of small and medium audit firms (REA and REGA), nevertheless remained dissatisfied with the new Law due to the implications that the rotation of audit partners would have for small audit firms and self-employed auditors ${ }^{10}$ (Tiempo, 8 July 2002; El Mundo Nueva Economía No. 138, 28 July 2002 ${ }^{11}$; Cinco Días, 1 October 2002; Expansión, 24 October 2002). However, as with the political groups in parliament, professional associations did make no reference to the previous experiences in Spain with mandatory audit firm rotation. 


\section{DISCUSSION AND CONCLUSIONS}

Narratives, rather than simply offering some chronological listing of facts, can be employed to configure and evaluate events (Parker, 1999, p. 23). This paper has sought to cast more detailed light on the frequently asserted claim these days that "mandatory audit firm rotation did not work in Spain" by reviewing what really has happened in Spain in parliamentary and professional circles since such a requirement was first introduced in 1988. Instead of the traditional view put over by the international accounting profession of an experiment that did not work (e.g., ICAEW, 2002; FEE, 2004) the removal of mandatory audit firm rotation emerges as a process that was never given the chance to work. Such a regulatory provision was removed not because of its failed practical impact, but more because it was politically convenient for a government seeking to secure support for other reforms and also because of what it said about the status of the Spanish auditing profession.

The essential puzzle with the Spanish case regarding mandatory audit firm rotation is why there has never been any detailed analysis of its capacity, in the specific context of the Spanish auditing market, to deliver improvements in audit quality. Bougen \& Vázquez (1997) once spoke highly of the awareness among Spanish politicians of the practical issues and consequences associated with changing Spanish accounting and auditing regulations - and how the level of political debate seemed much more sophisticated in terms of its understanding of auditing than that reflected in the type of public proclamations made about auditing in the general and business media (for a review of such proclamations, see GarcíaBenau \& Humphrey, 1992). The debate on mandatory audit rotation, however, seems a long way from such claimed levels of sophistication. There is also no evidence to support Bougen \& Vázquez's (1997) conclusion that Spanish politicians seek to make sure that any company legislation is appropriate for the specific context of Spain and show a marked reluctance to accept blindly the capacity of auditing to deliver particular things (Bougen \& Vázquez, 1997 pp. 4-5). Admittedly, the mandatory audit firm rotation was never allowed to operate in practice in Spain. However, collectively, the various debates in the Spanish parliament over the last decade on mandatory audit firm rotation have made no reference to Spanish experience with such a regulatory requirement - neither in terms of how (and why) it was established in Spain in 1988, whether it had ever operated and why it was removed in 1995. When discussing the development of the 1988 Audit Law, Bougen (1997) noted that in the parliamentary debate opposition parties made little reference to the specific characteristics of the Spanish audit profession and provided no direct Spanish evidence of current audit practice to support their claim of auditing as a profession (Bougen, 1997, p. 768). Instead, they made comparative references to other countries and international experiences (e.g., Japan and US). A similar behaviour was found in our analysis of the parliamentary discussions of issues related to mandatory audit firm rotation: Spanish politicians did not make any references to the previous experiences of Spain with such policy; instead, they relied upon EU guidance and the experiences from other countries to support/reject such a policy (without considering their capacity to deliver in the Spanish context).

Spain has been held up as a case of practical experience ruling out over regulatory dogmatism but in reality practical experience of auditing in Spain has had no obvious influence over the removal or subsequent proposals to reintroduce mandatory audit firm rotation. Classically, when other countries, post-Enron, were holding up Spanish experiences as a reason why not to pursue such a regulatory reform, the Spanish government was responding to Enron by seeking to introduce a 12 year mandatory audit firm rotation period. Similarly, the socialist party (PSOE) when it was in government, both approved and later removed (in 1988 and 1995 
respectively) mandatory audit firm rotation without ever demonstrating why it should work or why it wasn't working. Indeed, it does appear that political support for, or rejection of, particular regulatory options has been rather more opportunistic and rather less based on the logical outcome of a particular form of reasoning - for instance, "this is a reform being supported by the EU, we need to back it".

One possible way of resolving the basis on which regulatory reforms are being implemented or rejected is to view the approach to mandatory auditor rotation in Spain from a broader public policy perspective. Studies of Spanish politics have highlighted that numerous policies passed by Spanish governments never get implemented in practice (see Gibbons, 1999). It has been argued that the absence of sufficient political will among those making policy, the technical difficulties unforeseen by those who draft legislation to implement policy and residing policy ambiguities ${ }^{12}$ may explain why some government policies do not become operational in Spain (Gibbons, 1999, pp. 130-132). In the case of mandatory audit firm rotation, there are grounds for suggesting that the measure was included in the 1988 Audit Law for "symbolic" rather than "real" implementation. From such a perspective, the PSOE government in the late 1980s could be held to have used the regulation to reinforce the message that the new market for audits would operate with certain restrictions established by the state. As pointed out by Edelman (1960, p. 703), "this is not to suggest that signs or symbols in themselves have any magical force as narcotics. They are, rather, the only means by which groups not in a position to analyse a complex situation rationally may adjust themselves to it, through stereotypization, oversimplification, and reassurance". For the PSOE government, faced with the task of creating a new, statutory corporate auditing system, the practical complexities of assessing the impact of mandatory audit firm rotation on audit quality and the market for auditing services probably mattered far less than the symbolic message that auditing was an activity that was going to be regulated by the state to a significant degree. This would accord with its refusal to recognise any historical privileges on the part of the existing auditing professional bodies in Spain and its decision to define auditing as an activity rather than a profession (see Bougen, 1997). Moreover, in promoting mandatory audit firm rotation again in 2002, the Spanish government may well have been engaged on a strategic or symbolic push to convince the audit profession that it was well advised to accept the "lesser evil" of mandatory audit partner rotation.

From the auditing profession's perspective it could also be argued that the removal of mandatory audit firm rotation was an equally symbolic issue. Its attempts to establish auditing as a profession rather than a business "activity" (Bougen, 1997) meant securing independence from the state and this was not possible while there was a regulation requiring auditors to resign their tenure no matter how successfully they had provided their professional service. Just as Hopwood (1994) noted how the true and fair override (at the time of the EU's Fourth Company Law Directive) took on symbolic qualities within the UK accounting profession, it could be argued that so too did the repeal of the mandatory audit firm rotation provision in Spain. It was not a case of rotation not working; it was just that claims to professional status could not sit side-by-side with such a legislative provision.

The literature on Spanish politics also suggests that we are unlikely ever to get definitive answers and closure on the case of mandatory audit firm rotation. For instance, it has been said that the (public) articulation of the claims of interest groups on a permanent and continuous basis in Spain has been hindered by a lack of institutional stability (Linz, 1981; Molins and Casademunt, 1999) - although this does not mean that particular social and economic interest groups do not exercise a decisive (private) influence on the policy-making 
process (Linz, 1981, p. 367). As Molins \& Casademunt (1999, p. 124) argued, "the interplay of personal relations and interests between political and economic powers has decisively conditioned the manner in which interest groups in diverse social sectors have become established and has forged a style of mediation in which having the right personal contact is prized and rewarded". As a political grouping, CiU (Convergència i Unió) clearly played a significant role in all discussions about the mandatory rotation of audit firms in Spain - with its position, as that of other relatively small political groups such as PNV (Partido Nacionalista Vasco - Basque Nationalist Party), being favoured by the way the Spanish elections in 1993 and 1996 led to periods of minority government. CiU was the only political party in parliamentary debates on auditing to highlight its links with the profession. However, the "behind the scenes" discussions and contacts between CiU, the government and the auditing profession have not been made (and given the above political traditions in Spain, are unlikely to be made) public.

The real irony in the Spanish developments is that the 1990s have seen the auditing profession in Spain shows some clear tendencies of acting more like a special interest group or a trade association rather than a professional body devoted to the public interest. Big firms representatives have increasingly come to dominate in terms of the formulation of audit policy and the public representation of such policies (e.g., see, for example, Ruiz-Barbadillo et al. 2000, p. 138 for a discussion of the issue of auditors' liability in Spain), while the largest professional body in Spain (ICJCE) no longer seems to have a stance or spokespeople capable of being distinguished from the large multinational firms (e.g., Serrano, 2002) ${ }^{13}$. Now the rhetoric has become client related - with the large audit firms referring to themselves as business advisers, the providers of business assurance and other "added-value" services: "We help organizations large and small, public and private by providing industry focused services" (PricewaterhouseCoopers Spain website ${ }^{14}$ ). Further, where audit was once supposedly valued for its professional attributes and qualities, increasingly within the Spanish profession (as in other jurisdictions - for example, see Sikka \& Willmott, 1995; Fogarty et al., 1997; Humphrey, Jones, Khalifa \& Robson, 2004) it is seen to be rather down-valued and of a lesser status (in terms of job satisfaction and career development) relative to activities such as management consulting (Cañibano \& Castrillo, 1999; Martínez-García, Fernández-Laviada \& Somohano-Rodríguez, 2000; Expansión, 3 March 2005; Pérez-López \& López-Gavira, 2005). Given such developments, one could have expected more debate in Spain (and more demands for such debate from external investor and stakeholder groups) on the revision and removal of mandatory audit firm rotation - especially when it was clear that the auditing profession was lobbying for such reforms.

However, in many respects what has happened with respect to mandatory audit firm rotation is not that surprising. Through a range of papers (e.g, García-Benau et al., 1999; RuizBarbadillo et al., 2000; Vico-Martínez, 2002), Spain has now been highlighted as having over-optimistic public expectations of auditing, a profession that has talked up a liability crisis and sought to challenge, if not undermine, the work of its independent audit regulatory body and major audit firms who, across a string of corporate scandals, seem to have been operating in questionable ways and circumstances. With professional bodies and firms principally out to protect and promote their self-interests, coupled with a government increasingly under pressure to conform to the norms of the international regulatory arena, a relatively dispassionate investing public, and minority political parties keen to make political deals, mandatory audit firm rotation may well have been destined to be removed in a fairly quiet fashion. 
The worry academically is that Spanish auditing research is struggling to get to the heart of what life is really like in professional auditing and regulatory circles. Much of this research still remains at a rule-based level (considering what auditing standards should be like and how responsibility of auditors is defined; e.g., Pacheco, 2000) or is focused on comparing the formal elements and components of different national auditing and accounting systems (e.g., Bello-Peribañez, 1997; Gonzalo-Angulo, 2002; Rodríguez-Hernández, 2003; De la PeñaGutiérrez, 2004). At a time, internationally, when there is so much current concern with issues of harmonisation and the development of global auditing and accounting standards, such a research concentration may be understandable but it is not sufficient. This paper, by analysing the regulatory process about mandatory audit firm rotation in Spain, has attempted to get "inside" Spanish auditing and regulatory circles. However, there is still a need to get answers to a vast array of questions as to whether and how the internationalisation of auditing systems has changed Spanish auditing firms, audit practices and regulatory approaches (e.g., RuizBarbadillo et al., 2000). With Spanish academics under pressure to publish internationally, but with a perceived bias against Spanish empirical case studies ${ }^{15}$, there has to be some doubt as to how much progress is going to be made in this area - particularly, if research access continues to be so difficult to secure in Spanish organisations. This would be a shame as there remain numerous issues of interest and international relevance to pursue in a contemporary Spanish auditing context. As this paper has shown, there are significant political dimensions associated these days with audit research. Just through the single regulatory issue of mandatory audit firm rotation, Spain changed from a country that seldom attracted the attention of the international professional accounting community to one that was quite central to critical international post-Enron regulatory debates. At another level, (specially commissioned) research was used to provide "valuable" empirical evidence on experiences with mandatory audit firm rotation, yet such "confidential" research studies not only proved difficult to access but also seemed to be of questionable empirical strength. One clear implication of this paper is the importance of being able to draw on academic commentaries of audit regulatory processes that have not been compromised by having their work agendas dictated to or manipulated by the professional accounting firms and bodies (for more discussion, see Mitchell, Sikka \& Willmott, 2001). Regulatory reform is too significant an issue to be left to the sole remit of the auditing profession and/or "commissioned" audit researchers and market research agencies.

This paper provides evidence on the way in which Spanish experience has been used (or misused) by professional associations and auditing firms in formulating as a foundation for their position regarding the policy of mandatory audit firm rotation. In so doing, it also lends support to those who have questioned the level of transparency and accountability in regulatory arenas and the extent to which the Big Four firms are now dictating policy processes (e.g., Sikka \& Willmott, 1995; Cooper et al., 1998; Gendron \& Bédard, 2001; Caramanis, 2002). Claims emanating from professional accounting circles need to be treated carefully and in-depth, independent research can play a significant role in today's international audit policy arena - in particular, clarifying some of the "taken for granted" arguments which are part of the rhetoric of professional bodies and international audit firms. The benefit of careful, detailed historical research in the area of auditor rotation has already been demonstrated by Zeff's (2002) analysis of the Du Pont company. With Spanish experiences with a policy of mandatory audit firm rotation having rapidly assumed international significance, it is hoped that the detailed analysis presented here has at least helped to set the historical record straight. 


\section{REFERENCES}

AICPA (1992). Statement of Position Regarding Mandatory Rotation of Audit Firms of Publicly Held Companies. American Institute of Certified Public Accountants, New York. http://www.aicpa.org/members/div/secps/lit/sops/1900.htm (accessed 2 October 2002).

Amesti, C. (1995). Modificaciones introducidas por la Ley 2/1995, de 23 de marzo, de sociedades de responsabilidad limitada en materia de auditoría, Revista de Derecho Bancario y Bursátil, Vol. 59(14), 785-787.

Arruñada, B. \& Paz-Ares, C. (1994). La rotación de los auditores, El País, 22 December.

Arruñada, B. \& Paz-Ares, C. (1995). Economic consequences of mandatory auditor rotation. (as quoted in ICAEW, 2002).

Arruñada, B. \& Paz-Ares, C. (1997). Mandatory rotation of company auditors: a critical examination, International Review of Law and Economics, Vol. 17, 31-61.

Bello-Peribañez, A. (1997). El régimen de independencia e incompatibilidades en la auditoría de cuentas, Partida Doble, No. 82, 56-71.

BOICAC No. 4 (1991). Boletín Oficial del Instituto de Contabilidad y Auditoría de Cuentas. January 1991. Madrid: Instituto de Contabilidad y Auditoría de Cuentas (ICAC).

BOICAC No. 5 (1991). Boletín Oficial del Instituto de Contabilidad y Auditoría de Cuentas. May 1991. Madrid: Instituto de Contabilidad y Auditoría de Cuentas (ICAC).

BOICAC No. 12 (1993). Boletín Oficial del Instituto de Contabilidad y Auditoría de Cuentas. March 1993. Madrid: Instituto de Contabilidad y Auditoría de Cuentas (ICAC).

BOICAC No. 21 (1995). Boletín Oficial del Instituto de Contabilidad y Auditoría de Cuentas. April 1995. Madrid: Instituto de Contabilidad y Auditoría de Cuentas (ICAC).

Bougen, P.D. (1997). Spain, July 1988: some observations on becoming professional, Accounting, Organizations and Society, Vol. 22(8), 757-77.

Bougen, P.D. \& Vázquez, D. (1997). Debating Spanish audit legislation: the Audit Law of 1988, The European Accounting Review, Vol. 6(1), 1-17.

Cadbury Committee Report (1992). Report of the Committee in the Financial Aspects of Corporate Governance. http://www.ecgi.org/codes/country_documents/uk/cadbury.pdf (accessed 2 October 2003).

Cameran, M., Livatino, M., Pecchiari, N. \& Vigano, A. (2003). A survey of the impact of mandatory rotation rule on audit quality and audit pricing in Italy, paper presented at the EARNET 2003, Second European Auditing Research Network Symposium. $31^{\text {st }}$ October$1^{\text {st }}$ November 2003, Manchester, UK. 
Cañibano, L. \& Castrillo, L.A. (1999). La independencia de los auditores: un nuevo enfoque, Actualidad Financiera, Año IV ( $3^{\circ}$ trimestre), 21-39.

Caramanis, C.V. (2002). The interplay between professional groups, the state and supranational agents: Pax Americana in the age of 'globalisation', Accounting, Organizations and Society, Vol. 27(4/5), 379-408.

Carnegie, G.D. \& Napier, C.J. (1996). Critical and interpretive histories: insights into accounting's present and future through its past, Accountability, Auditing and Accountability Journal, Vol. 9(3), 7-39.

Carrera, N., Gutiérrez, I. \& Carmona, S. (2005). Concentración en el mercado de auditoría en España: análisis empírico del período 1990-2000, Revista Española de Financiación y Contabilidad, Vol. XXXIII (125), 423-457.

Catanach, A.H. \& Walker, P.L. (1999). The international debate over mandatory auditor rotation: a conceptual research framework, Journal of International Accounting Auditing \& Taxation, Vol. 8(1), 43-66.

CGAAI (2003). Final Report of the Co-ordinating Group on Accounting and Auditing Issues to the Secretary of State and Industry and the Chancellor of the Exchequer (29 January 2003. URN 03/567), http://dti.gov.uk/cld/cgaai-final.pdf (accessed 13 February, 2005).

Chandler, R. \& Edwards, R.J. (1996). Recurring issues in auditing: back to the future?, Accounting, Auditing and Accountability Journal, Vol. 9 (2), 4-29.

Cooper, D.J., Greenwood, R., Hinings, B. \& Brown, J.L. (1998). Globalisation and nationalism in multinational accounting firms: the case of opened new markets in Easter Europe, Accounting, Organizations and Society, Vol. 23(5-6), 531-548.

Craswell, A.T. (1988). The association between qualified opinions and auditor switches, Accounting and Business Research, Vol. 19(73), 23-31.

De la Peña-Gutiérrez, A. (2004). Efectos de la regulación financiera: el caso de la auditoría, Partida Doble, No. 153, 84-96.

Deis, D.R. \& Giroux, G. (1996). The effect of auditor change on audit fees, audit hours and audit quality, Journal of Accounting and Public Policy, Vol. 15, 55-76.

Díaz, N. (1995). Auditores: libertad de contratación frente a rotación obligatoria, Expansión, 10 February, 1995.

Durández, A. (1991). La independencia del auditor. Una encuesta urgente, Partida Doble, Vol. 2, 35-37.

Edelman, M. (1960). Symbols and political quiescence, American Political Science Review, Vol. 54(3), 695-704.

EU (2002). Statutory Auditors' Independence in the EU: A Set of Fundamental Principles. Commission recommendation of 16 May 2002 (document number C(2002) 1873). 
http://europa.eu.int/eur-lex/pri/en/oj/dat/2002/1_191/1_19120020719en00220057.pdf (accessed 2 October 2003).

FEE (2004). Study on Mandatory Rotation of Audit Firms. Fédération des Experts Comptables. Européens. http://www.lar.lt/Docs/FEE\%20Study\%20on\%20Mandatory \%20Rotation\%20of\%20Audit\%20Firms\%200410.pdf (accessed 27 November 2004).

Fogarty, T.J., Zucca, L.J., Meonske, N. \& Kirch, D.P. (1997). Proactive practice review: a critical case study of accounting regulation that never was, Critical Perspectives on Accounting, Vol. 8(3), 167-187.

Francis, J.R. (2004). What do we know about audit quality?, The British Accounting Review, Vol. 36(4), 345-368.

Funnell, W. (1996). Preserving history in accounting seeking common ground between "new" and "old" accounting history, Accounting, Auditing, and Accountability Journal, Vol. 9(4), 38-64.

Funnell, W. (1998). The narrative and its place in the new accounting history: the rise of the counternarrative, Accounting, Auditing \& Accountability Journal, Vol. 11(2), 142-162.

GAO (2003). Public Accounting Firms: Required Study on the Potential Effects of Mandatory Audit Firm Rotation. Report of the Government Accountability Office to the Senate Committee on Banking, Housing, and Urban Affairs and the House Committee on Financial Services. http://www.gao.gov/new.items/d04216.pdf accessed 27 August $\underline{2004})$.

García-Benau, M.A. \& Humphrey, C. (1992). Beyond the audit expectation gap: learning from the experiences of Britain and Spain, The European Accounting Review, Vol. 1(2), 303-331.

García-Benau, M.A., Humphrey, C., Moizer, P. \& Turley, S. (1993). Auditing expectations and performance in Spain and Britain: a comparative analysis, The International Journal of Accounting, Vol. 28(4), 281-307.

García-Benau, M.A., Ruiz-Barbadillo, E., Humphrey, C. \& Al Husaini, W. (1999). Success in failure? Reflections on the changing Spanish audit environment, The European Accounting Review, Vol. 8(4), 701-730.

García-Benau, M.A. \& Laínez-Gadea, J.A. (2004). Forever destined to be extras in a Broadway show: a discussion of the status of national accounting research in an international arena, in: C. Humphrey \& W.J. Lee (Eds.) The Real Life Guide to Accounting Research: A Behind-the-Scenes View of Using Qualitative Research Methods, Section 1: The meaning of research, Elsevier Science, Oxford.

Gendron, Y. \& Bédard, J. (2001). Academic auditing research: an exploratory investigation into its usefulness, Critical Perspectives on Accounting, Vol. 12(3), 339-368.

Gibbons, J. (1999). Spanish Politics Today, Manchester: Manchester University Press. 
Gonzalo-Angulo, J.A. (1995). La auditoría, una profesión en la encrucijada de los noventa, Revista Española de Financiación y Contabilidad, Vol. XXIV(84), 595-629.

Gonzalo-Angulo, J.A. (2002). Las líneas básicas de la reforma contable, Partida Doble, No. $136,10-27$.

Gonzalo-Angulo, J.A. \& Gallizo, J.L. (1992). European Financial Reporting -Spain London: Routledge.

Hopwood, A. (1994). Reflections on the harmonization of accounting in the European Union, The European Accounting Review, Vol. 3(2), 241-254.

Humphrey, C., Jones, J, Khalifa, R. \& Robson, K. (2004). Business risk auditing and the auditing profession: status, identity and fragmentation, paper presented at the CARR/University of Manchester ESRC Workshop on Auditing in Action, London School of Economics, London, February (see http://www.lse.ac.uk/collections/CARR/ events/previousConferencesWorkshops/auditingPresentations/humphrey.pdf).

ICAEW (2002). Mandatory Rotation of Audit Firms (ICAEW: London) http://www.icaew.co.uk/publicassets/00/00/03/64/0000036465.PDF (accessed 2 October 2002).

Iglesias, J.L. (1994). La duración del cargo de auditor. Consideraciones críticas, Revista de Sociedades, Vol. 3, 11-33.

Johnson, V., Khurana, I. \& Reynolds, J. (2002). Audit-firm tenure and the quality of financial reports, Contemporary Accounting Research, Vol. 19(4), 637-660.

Lee, T. (1995). The professionalization of accountancy: a history of protecting the public interest in a self-interested way, Accounting, Auditing \& Accountability Journal, Vol. 8(4), 48-69.

Lennox, C. (2000). Do companies successfully engage in opinion-shopping? Evidence from the UK, Journal of Accounting and Economics, Vol. 29, 321-337.

Ley 2/1995 de 23 de Marzo de Sociedades de Responsabilidad Limitada. Boletín Oficial del Estado (BOE) Num. 71 de 24 de marzo de 1995.

Linz, J. J. (1981). A century of interest politics in Spain", in: S. Berger (Ed) Organizing Interests in Western Europe, Cambridge: Cambridge University Press.

López-Combarros, J.L. (1996). Propuestas para una modificación de la ley de auditoría de cuentas, Partida Doble, No. 71, 42-49.

Martínez-García, F.J., Fernández-Laviada, A. \& Somohano-Rodríguez, F. (2000). La situación de la auditoría en Cantabria: una aportación al debate sobre la función actual de la auditoría, IX Encuentro de Profesores Universitarios de Contabilidad, Las Palmas de Gran Canaria. 
Mills, P. (1990). Agency, auditing and the unregulated environment: some further evidence, Accounting, Auditing \& Accountability Journal, Vol. 3(1), 54-66.

Mitchell, A., Sikka, P. \& Willmott, H. (2001). Policing knowledge by invoking the law: critical accounting and the politics of dissemination, Critical Perspectives on Accounting, Vol. 12(5), 527-555.

Moizer, P. (2003). How published academic research can inform policy decisions: the case of mandatory rotation of audit appointments, Working Paper 28/03/03, Leeds University Business School, University of Leeds.

Molins, J.M. \& Casademunt, A. (1998). Pressure groups and the articulation of interests, West European Politics, Vol. 21(4), 124- 146.

Morlino, L. (1995). Political parties and democratic consolidation in Southern Europe, in: R. Gunther, P. N. Diamandouros \& H. Puhle (Eds) The Politics of Democratic Consolidation. Southern Europe in Comparative Perspective, 315-388, London: The Johns Hopkins University Press.

Navarro-Gomollón, A.J. \& Bernad-Morcate, C. (2004). Las sanciones impuestas a los auditores: un indicador de la calidad de las auditorías, Partida Doble, No. 156, 6-19.

$\mathrm{Ng}$, C. (2003). Rotation of auditors: history and recent developments, paper presented at the 3rd Accounting History International Conference 2003, Siena, 17-19 September 2003.

Pacheco, M. (2000). Régimen Legal de la Auditoría de Cuentas y Responsabilidad de los Auditores. Consejo Económico y Social: Colección Estudios, No. 92, Madrid.

Parker, L.D. (1999). Historiography for the new millennium: adventures in accounting and management, Accounting History, Vol. 4(2), 11-42.

Pérez-López, J.A. \& López-Gavira, R. (2005). Y después de la reforma de la Ley de Auditoría: ¿qué siguen haciendo los auditores?, Partida Doble, No. 164, 96-109.

Petit, M.V. (1995). La supresión de la regla de rotación obligatoria en el nombramiento de auditores de cuentas por la Ley 2/1995, de 23 de marzo, de Sociedades de Responsabilidad Limitada, Revista General de Derecho, No. 609, 6903-6911.

Petty, R. \& Cuganesan, S. (1996). Auditor rotation: framing the debate, Australian Accountant, Vol. 66(4), 40-41.

Pong, C.K.P. (1999). Auditor concentration: a replication and extension for the UK audit market (1991-1995), Journal of Business Finance and Accounting Vol. 26(3-4), 451475 .

Prado-Lorenzo, J.M., Gonzalo-Bravo, I. \& Martín-Jiménez, D. (1995). La situación de la auditoría en España desde la perspectiva de los auditores, Revista Española de Financiación y Contabilidad, Vol. 24(84), 631-666. 
Previts, G.J., Parker, L.D. \& Coffman, E.N. (1990). Accounting history: definition and relevance, Abacus, Vol. 26(1), 1-26.

PricewaterhouseCoopers (2002), "Corporate governance and the integrity of capital markets", Views, 2 (May). http://www.pwcglobal.com/images/au/abas/views/views_4.pdf (accessed 2 October 2002).

Raghunanthan, B., Lewis, B. \& Evans, J. (1994). An empirical investigation of problem audits, Research in Accounting Regulation, Vol. 8, 33-58.

REA (2002). Propuestas del Registro de Economistas Auditores del Consejo General de Colegios de Economistas de España a las Enmiendas del Grupo Popular del Senado al Proyecto de Ley Financiera en aquellos aspectos que afectan a la Ley de Auditoría de Cuentas. Septiembre 2002. Madrid: Registro de Economistas Auditores, Consejo General de Colegios de Economistas.

REGA (2002). Comentarios a las reformas en materia de auditoría introducidas en el Proyecto de Ley de Medidas de Reforma del Sistema Financiero. Ponencia de Lorenzo Lara, Presidente del REGA, XIII Forum del Auditor Profesional, Barcelona, $5^{\text {th }}$ July 2002.

Rodríguez-Hernández, J. (2003). La deontología del auditor ante la reforma de la ley de auditoría, Partida Doble, No. 146, 76-81.

Ruiz-Barbadillo, E., Humphrey, C. \& García-Benau, M.A. (2000). Auditors versus third parties and others: the unusual case of the Spanish audit liability 'crisis', Accounting History, Vol. 5(2), 119-146.

SDA Universitá Bocconi (2002). The Impact of Mandatory Audit Rotation on Audit Quality and on Audit Pricing: the Case of Italy (as quoted in ICAEW, 2002).

Serrano, F. (2002). "Economista, una profesión cualificada y con multiactividad. Entrevista a Don Fernando González-Moya Rodríguez de Mondelo, Partida Doble, No. 139, 6-13.

Sikka, P. \& Willmott, H. (1995). The power of "independence": defending and extending the jurisdiction of accounting in the United Kingdom, Accounting, Organisations and Society, Vol. 20(6), 547-581.

UK House of Commons (2002), Minutes of Evidence. Discussion of the Memorandum submitted by the Review Board, the Auditing Practices Board and the Ethics Standards Board of the Accountancy Foundation, 25 June 2002. http://www.parliament.thestationery- office.co.uk/pa/cm200102/cmselect/cmtreasy/758/2062506.htm (accessed 2 October 2003).

US House of Representatives (2002), Committee on Financial Services 13 March 2002. http://commdocs.house.gov/committees/bank/hba78501.000/hba78501_0.HTM (accessed 2 October 2002).

Vico-Martínez, A. (2002). El caso Gescartera y la futura ley financiera: implicaciones para la auditoría y la contabilidad, Partida Doble, Vol. XII(134), 28-35. 
Wolk, C.M., Michelson, S.E. \& Wootton, C.W. (2001). Auditor concentration and market shares in the US: 1988-1999 A descriptive note, British Accounting Review, Vol. 33, 157-174.

Zeff, S. A. (2003). Du Pont's early policy on the rotation of audit firms, Journal of Accounting and Public Policy, Vol. 22(1), 1-18.

\section{Notes}

1. https://icanztest.icanz.co.nz/StaticContent/download/AGS/grsccgr.doc (accessed 23 September 2005).

2. http://www.lar.lt/Docs/FEE\%20Study\%20on\%20Mandatory\%20Rotation\%20of\%20Audit\%20Firms\% 200410.pdf (accessed 27 November 2004).

3. The date of the removal is 1995 , not 1997 as stated in the paper $(\mathrm{Ng}, 2003$, p. 2).

4. Spain has a bi-cameral parliament consisting of two chambers: the Congress of Deputies (Congreso) and the Senate (Senado). Draft parliamentary bills (anteproyectos de ley) are initially prepared in governmental ministries and approved and amended, if necessary, by the Cabinet. Once they become proper parliamentary bills (proyectos de ley) and published in the Official Journal of the Congress (Boletín Oficial de las Cortes), they are available for public scrutiny. After a bill is published a time frame of fifteen days is opened in which parliamentary groups can present amendments, to either the whole text or partial amendments to certain sections. The first debate in the Plenary Sitting takes place once the time limit for presentation of amendments has passed. The debate usually begins with the introduction of the text by a member of the Government. Then a report is made, based on the text, by a Member of the Committee working on the bill. Once the presentation has finished, the debate is governed according to the dispositions of the Speaker, heard by the Bureau and the Board of Spokesmen. Thanks to the application of a special procedure, known as the full legislative authority of the Committee, the bill can go directly to the Senate after its approval by the Committee. In the Senate, a similar pattern prevails, although within a more restricted period of time. After a spell in the Senate, bills are brought back to the Congress where they are presented for final approval or rejection, including any amendments proposed by the Senate (Gibbons, 1999, p. 104; www.congreso.es -accessed 10 February 2005).

5. In 1996, after 14 years in government, the Socialist Party (PSOE) lost the general elections. The conservative party (PP) led by José María Aznar, was unable to capture sufficient votes to command an overall majority in the Spanish parliament so they needed the support of Catalan and Basque nationalists groups (Convergència $i$ Unió (CiU) and Partido Nacionalista Vasco (PNV)) to form a government. In the general elections of 2000, PP won the elections again but this time with sufficient votes to have an overall majority in the Spanish parliament.

6. Spain had taken over the rotating presidency of the EU in January 2002, meaning that, at the time of the ECOFIN meeting in Oviedo (Spain), Spain was effectively leading the EU. While the opposition parties such as PSOE and CiU followed the ECOFIN recommendations, this was not the case for the Spanish governing party, PP. It would also appear that PP's proposals for mandatory audit firm rotation were not that influential, if discussed at all, at the ECOFIN meeting.

7. The EU recommendations include audit partner rotation in the following terms: "as a minimum to replace the Key Audit Partners of the Engagement Team (including the Engagement Partner) within 7 years of appointment to the Engagement Team. The replaced Key Audit Partners should not be allowed to return to the Audit Client engagement until at least a two years period has elapsed since the date of their replacement" (EU, 2002).

8. In the Congress and Senate political parties are categorised by parliamentary groups. The Partido Popular (PP) forms the "Grupo Popular" (Popular Group); the Socialist Party (PSOE) is called the "Grupo Socialista" (Socialist Group). CiU on its part belongs to the "Grupo Catalán" (Catalonian group).

9. PP and CiU co-operated not only in relation to regulations on auditor rotation, but also in terms of a number of other rules and measures included in the Financial Law. This Law, which was the most 
important reform of financial regulation in Spain in recent years, modified around twenty financial existing rules, the most controversial ones being those relating to the regulation of saving banks (Cajas de Ahorros). Although a description of the main changes derived from the approval of the Financial Law goes beyond the purpose of this paper, it is worth noting that PP and CiU also worked together on regulations relating to saving banks and measures and mechanisms to promote the development of SMEs - an issue that was common to the agenda of both political parties since early 2001 (Expansióndirecto, 12 March 2001).

10. For a one partner practice, audit partner rotation would effectively mean audit firm rotation.

11. http://www.el-mundo.es/nuevaeconomia/2002/138/1027756857.html

12. For instance, the 1985 Spanish Tax Act enabled savers a form of legal tax evasion as a consequence of some weaknesses in the law (Gibbons, 1999, pp. 130-132).

13. For a discussion on this issue in a Greek context, see Caramanis (2002).

14. Headline of PricewaterhouseCoopers website in Spain -accessed 23 September 2005; http://www.pwc.com/es/eng/main/home/index.html. See also Pérez-López \& López-Gavira (2005) for a description of the main activities undertaken by the main audit firms in Spain (both national and international audit firms).

15. To the extent that Spanish cases are either not researched, referred to as "intriguing" or "unusual" cases to justify their presence or have all Spanish traces, including Spanish references, removed from them in attempt to bolster the chances of convincing international referees that the paper makes a significant contribution to knowledge - for more discussion, see García-Benau \& Lainez-Gadea, (2004). 
TABLE I

AUDITOR ROTATION 2002: LEGISLATIVE PROCESS

\begin{tabular}{|c|c|c|c|c|c|c|c|}
\hline DATE & $\begin{array}{l}\text { POLITICAL } \\
\text { GROUP }\end{array}$ & DOC $^{1}$ & $\begin{array}{l}\text { MANDATORY } \\
\text { ROTATION }\end{array}$ & YEARS $^{2}$ & WHO ROTATES? & $\begin{array}{l}\text { WHICH COMPANIES ARE SUBJECT TO MANDATORY } \\
\text { ROTATION? }\end{array}$ & JUSTIFICATION \\
\hline \multicolumn{8}{|c|}{ PARLIAMENT } \\
\hline 08/03/02 & PP & $\begin{array}{l}\text { Financial } \\
\text { Law Bill }\end{array}$ & NO & & & & \\
\hline 17/05/02 & PSOE & $\mathrm{Am}^{3} .114$ & YES & 5 & Partner and Audit Team & $\begin{array}{l}\text { Listed companies, companies in which the public sector participates, and } \\
\text { in general, all companies subject to mandatory audit }\end{array}$ & ECOFIN recommendations \\
\hline 17/05/02 & PP & Am. 168 & YES & 12 & $\begin{array}{l}\text { (a) Audit firm } \\
\text { (b) Partner and audit team }\end{array}$ & $\begin{array}{l}\text { (a) Listed companies } \\
\text { (b) No listed companies under public supervision }\end{array}$ & $\begin{array}{l}\text { To ensure the independence of the } \\
\text { auditor }\end{array}$ \\
\hline 17/05/02 & $\mathrm{CiU}$ & Am. 241 & YES & 7 & $\begin{array}{l}\text { Auditor (if self-employed) } \\
\text { Audit partner otherwise }\end{array}$ & $\begin{array}{l}\text { Listed companies and companies subject to the supervision and control of } \\
\text { the Bank of Spain or to the Financial Services Authority }\end{array}$ & $\begin{array}{l}\text { Recommendations of the EU (Dublin, } \\
\text { 2002; ECOFIN, Oviedo, 2002) }\end{array}$ \\
\hline 29/05/02 & $\mathrm{CiU}+\mathrm{PP}$ & Ad. $\mathrm{Am}^{4}$. & YES & 7 & Partner and audit team & $\begin{array}{l}\text { Companies under public supervision, listed companies, and companies } \\
\text { with turnover higher than } 30 \text { million euros }\end{array}$ & \\
\hline $11 / 06 / 02$ & \multicolumn{2}{|c|}{ Final Report Congress } & YES & 7 & Partner and audit team & $\begin{array}{l}\text { Companies under public supervision, listed companies, and companies } \\
\text { with turnover higher than } 30 \text { million euros }\end{array}$ & \\
\hline
\end{tabular}

SENATE

\begin{tabular}{|c|c|c|c|c|c|c|c|}
\hline 17/09/02 & PSOE & Am. 179 & YES & 5 & Partner and audit team & $\begin{array}{l}\text { Listed companies, companies where public sector participate in some } \\
\text { proportion, and in general, all companies subject to mandatory audit }\end{array}$ & ECOFIN recommendations \\
\hline 17/09/02 & $\mathrm{CiU}$ & Am. 207 & YES & 7 & Partner and audit team & $\begin{array}{l}\text { Companies under public supervision, listed companies, and companies } \\
\text { with turnover higher than } 60 \text { million euros }\end{array}$ & \\
\hline 7/10/02 & \multicolumn{2}{|c|}{ Final Report Senate } & YES & 7 & Partner and audit team & $\begin{array}{l}\text { Companies under public supervision, listed companies, and companies } \\
\text { with turnover higher than } 30 \text { million euros }\end{array}$ & \\
\hline
\end{tabular}

\section{PARLIAMENT}

08/11/02 Final Law

YES

Partner and audit team

Companies under public supervision, listed companies, and companies with turnover higher than 30 million euros

${ }^{1}$ Document containing the proposa

${ }^{2}$ Years: Number of years before mandatory rotation

${ }^{3}$ Am.: Amendment ${ }^{4}$ Ad. Am.: Additional amendment

${ }^{4}$ Ad. Am.: Additional amendment 